\title{
Female's Consciousness Shift from Perception to Rationality
}

\author{
Yanyan LEI \\ The Department of Foreign Language \\ Hechi University \\ Yizhou,Guangxi, 546300, China
}

\begin{abstract}
In the "Sense and Sensibility", the sensible Elinor and Marianne are two greek sisters with sensual personality differences, their heroes in this work with three different attitude reflect two sisters Sense and Sensibility, after the opposition, but his sister Marian paid a heavy price for their sensibility, her attitude gradually transformed from the perception to rationality.
\end{abstract}

Keywords- Sense and Sensibility; Female'sConsciousness; Austin

\section{INTRODUCTION}

Jane Austen (1775-1817) was one of the most famous feminist writers of the 19th century early 18th century England, as for the development of female literature she had an important impact. Jane Austen eyes cast on the issue of youth, women are concerned about marriage and family, her life, though only completed six novels, but some people think that she in the history of English literature like Shakespeare plays an important role, Fitch said, one of the world's greatest writer. Her first novel creation of "Pride and Prejudice" was published in 1813; it marks the arrival of the era of women's literature. Jane Austen then carried her second novel, "Sense and Sensibility" in writing, and then had completed the "Mansfield Park" (1814), "Emma" (1816), "Northanger Abbey" (1818) and "persuasion " (1818). Live in an era in Austin, patriarchal status in her literary works is reflected. Virginia - Wolf believes that in the early 19th century, women mostly had autobiographical novel, leading to one of the motivations of their writing, which is the desire to reveal the pain suffered by their ownto defend themselves, Austin is such a bits that are used to express the novel a writer on women's issues, whether it is "Pride and prejudice" or "Sense and Sensibility", that are in the United Kingdom at the time of the country's love affair decent people as a theme, she was most concerned about the people there tend to be decent no fat lady's marriage dowry.

Sensibility was born, without modification, wild and primitive, irrational in social morality, public order, education nurtured slowly formed. The higher the education level, the less people suffer, it should be more rational component, and emotional time. In Jane Austen's "Sense and Sensibility", the representative Elinor is rational, calm and rational which is a knowledgeable, sensible, failing to understand the ideal woman calm and restrained emotion, and Marianne represents the wayward impulsive, careless, unrestrained pursuit of female romantic life. The novel's end, Marian's character and attitude are also affected by the perceptual Eleanor turned his mind. Elinor and Marianne are two extremely opposite character sister, personality differences led to the sisters with different styles and deal with feelings, this article has only the attitude of the two sisters, Willerby and Edward and Colonel Brandon have analysis of their personality differences, and feminist consciousness by Marianneperception to rationality change.

Second, Eleanor Rational Emotional Expression

Eleanor character is calm, subtle and is not exposed, she was always able to use calm and objective look upon the people and things. Her heart is the same longing for love, but she and her sister opposite reason is that he can use to control their emotions. As she puts it: "Do not intentions, to use my mind, a little sanity."

\section{TREAT EDWARD}

In the whole work, she had only just once strongly expressed her appreciation and love for Edward: "He has remarkable insight and integrity, because she was naturally shy, often reticent, sometimes nearly as good - - I'm sure, he was knowledgeable, love of reading, imagination, observation questions accurately, and pure fun. But, you see him who has very touching eyes, you will find that his entire face are very lovely. "

This is the only time Elinorthat cannot help but express love for Edward, but after a series of many things happen, Elinor could use reason to control his passions, Elinormakes them a family in Devon Country House to find a new home, which also led to her beloved Elinor and Edward break up.

Fiction best embody the sense and strong things when Lucy and Edward told Eleanor that she had engaged in what performance after Eleanor. The news is simply bolt from the blue for Eleanor, because she has been in love with Edward and others engaged, beginning when she was deceive ourselves that this is not true, because she did not dare to accept the reality, but she confirmed that the news is true, she's strong performance and the reason it out. "It is strange, Eleanor with sadness and embarrassment gripping said, I actually never heard, he mentioned your name."

When she saw a small photo exhibit of Edward and his handwriting, she admitted that he can no longer deceive us, 
but she calmly answered that Lucy asked her, in her calm voice behind, she never felt hidden excitement and sadness, and she felt humiliated, shocked and terrified. But she did not like her sister who did enjoy others to express their feelings, but to the great suffering is deeply concealed up, and the surface is quite cool, as is her family not to worry, this is difficult to imagine how weak woman bear pain.

\section{A. Treat Colonel Brandon}

Eleanor objective and fair view of everyone are around her, including Willerby and Marian are very nasty to Colonel Brandon, Willerby and Marian think Colonel Brandon are the kind of verbal praise, and within the heart of people do not like.Andit often opens his joke, visibility and they have hated to and Colonel Brandon, but Eleanor did not think so:

"You have to give him all of a sudden made up so many shortcomings," Eleanor said, "it is completely relying on your own imagination, in contrast, I praise him becomes dull, I can only say that he is a very sensible person, welleducated, well-informed, manners, and I think he was generous heart. "

Eleanor's view is that "Colonel Brandon is a very sensible person, but for a reason I always glamorous. Yes, Marianne! Even he is a thirty-four-year-old man. He saw the world more, been abroad, read many books, there is a good thinking mind and showing good education and temperament.

\section{B. Treat Willerby}

When Willerby did not give any explanation on the left Marian, Eleanor and her mother are very sad, but angrily Marianne did not understand my sister's goodwill, directed vociferous sister: "But you Well Eleanor, love this suspicion that the suspect ...... I know, I will not call you a satisfactory explanation, but you cannot convince me to give my opinion. I know you will say to me, things may be so, may not be so picky, I do not want to hear those words you, unless you can make a satisfactory explanation to the same. Well, Eleanor, what do you say?"

Marian even is with the tone of this unwarranted provocation, Eleanor's tolerance and sanity once again shows up. She knew her sister at this time the mood is quite painful, so she does not care about how much they have been grievances, although she was not suffering much difference than her sister, she was calm and sensibly replied: "No, because you have thought so, how would I answer."

In her view, Willerby the man is not as perfect wife and Marianne Dashwood in the eyes, she felt Willerby say too much, regardless of others, regardless of the occasion, easily commentators, the letter I and out, and despite the generally polite, but too mundane routine contempt. She concluded that his words and deeds of this indiscretion, no matter how he defended himself and Marianne, Elinor could not agree.

Eleanor has a rational look at everyone around her, according to the words of other people who have said and done things to rational evaluation of a person, which is exactly the reason, she finally won happiness.

\section{C. , the performance of sensual emotions of Marian}

When Elinor frown to calculating rent bills and expensive beef, Marian is longing for the storm in love and yearning among sonnet. In addition to her beloved Willerby, she almost does not care about anyone, Marian character is hot and dares to hate, hassensibility to do everything.

1) Treat Edward

Marian is a straightforward character that had the courage to see the girl bluntly, she is not bound by secular philosophy, such as treatment of Edward's attitude; she and her sister are very different views. When Marianne found her sister to Edward became interested when she expressed their views on Edward. "I am a bit surprised. Edward is very amiable, and I loved her, but he was not the kind of young man ... he was missing something, he askew striking image. I do not think you can really catch my sister the kind of charm, he does not have a shred of his music ...... almost unattractive, although he admired Elinor paintings, but that's not to enjoy ...... insiders last night when he read aloud to us, looks listless, thoroughly bad! I'm worried for my sister. "

Seen in Marianne's eyes, Edward is no merit, her ideal man should have good looks, the heart must be like fire and passion, but also for literature and art should have high attainments, not like Edward so homely and very calm mind, his body cannot make people experience the passion of the people.

\section{TREAT COLONEL BRANDON}

Colonel Brandon Marian always cherishes some disgust, and always uses language taunt him mercilessly. "You heard what he had rheumatism? Is not this the most common disease of aging it? But by the age of 35 should not be considered married ..."

Marian treat Colonel Brandon's attitude and the attitude of Colonel Willerby is the same, Willerby thinks Colonel Brandon is the kind of verbal thing and everyone praised him, but at heart who do not like him . "This is my opinion." Marianne cried.

Visibly, Marian ideal mates have romantic composition, which led to her later handsome appearance ofWillerby, falling love at first sight, with all his emotions into this sanctimonious hypocrite body.

In the first volume of the seventh chapter, there is a paragraph on Colonel Brandon's physical description. "His appearance is not quite annoying, although Marianne and Margaret thought he was an old bachelor, though it is not very hate.He's handsome than Willerby, sometimes it is a little despise Marianne Brandon, she thinks he is not lively enough but too young, she always turns a blind eye to his advantage, but it is such a man who later becomes Marian's husband."

\section{TREAT WILLERBY}

When Marian first met Willerby, it was his charming appearance and temperament deeply attracted, emotional thing completely prevailed, and she selflessly put into that field of love. With the rapid development of Marian and Willerby's feelings, two people are interested in music and 
dance, and this hobby is also due to their views on exactly the same between the two. They are surprisingly similar interests; they worship the same books paragraph. Soon, Willerby became his entire life; she does not want anyone to say a little something about bad between her and Willerby, including her sister Eleanor. The two of them at once had a cordial conversation, he told his little sister Eleanor! "You did this morning, it is useful results on almost all issues that have a clear idea of Mr. Wheeler insights goodbye than a face, you will. His views on beauty and remarriage explain clearly, as you will not have something good to ask a... Who knows, but it's words angered Marianne, "Eleanor," Marianne cried to "say that fair?Is itreasonable? I thought so poor? Ithas been too comfortable, too happy, and too frank. it violated the stereotypes discerning etiquette. "

When her cousin, Sir John said she was teasing Willerby, Marian angrily said: "Sir John, this argument I especially hate you, what words are vulgar wisecracks when speaking, people really hate what tease men Yeah, Yeah conquer men, particularly macabre, so no vulgar words are educated. "

\section{MARIAN CONVERTED BY INDUCTIVE INTELLECT}

When they arrived in London with two sisters, Marian cannot wait to write to Willerby, when my sister saw her sister's face when the two of them have been engaged to be sure. Marian writes the letter, quickly.The letter was sent to the post office, as night fell, Marian was getting restless, almost anything she could not eat for dinner, after dinner, she was back to the living room; she seemed uneasy and anxious to listen the voice of every carriage. When Marian knows the truth after all, she accepted the reality of combat romance, after being polished edges reality, she was able to look at life with rational thinking, and she almost died in the storm, Brandon Colonelsaved her. She is sensual and capricious regret the year, she married Colonel Brandon, accepted the fate of the woman's shelter, eventually turned from the emotional reason.

\section{CONCLUSIONS}

Austin had warned the woman how to get a happy marriage. That is to use reason to control emotions, to pay her boyfriend in the process, which should be cautious, not easily emotional, capricious act, if both men and women in the poor condition, or the woman's emotional, it will be greatly traumatized, which is unable to extricate himself. "Sense and Sensibility" in the first Marian is such a woman, her sensibility prevailed, Eleanor based on a keen intellect and rational conscience at peace of mind panic disorder; Marian's mettle is derived from the rational weak and emotional control. Also treat emotional, also face the same choice, the sisters have made a different decision, showing very different values, along with the nature of Willerby seducer gradually exposed, and sensual superficial idea of Marian held on and stand out. Critic Patricia Myers - Parker said: "intellect makes them aware of the time dependence of women and their needs, aware of the need to protect this that has on their lives." Even Marian, as the overly sentimental, romantic love holding fantasy hero, eventually succumbed to this necessity. Although initially she felt for her husband just filled with intense feelings of admiration and friendship, not love. But Marian had learned to compromise the economic environment, the emotional compromise eventually made her emotional sensibility into a reason.

\section{References}

[1] Liu Xiamin.The romantic to the new secular women [J] Xiangtan Normal University, 2006 (6)

[2] The reason the pool clean comedy emotional tragedy [J] Nanjing University, 2000 (6).

[3] Li Zhongying, Guqiu Yan feminist embodied in Sense and Sensibility in [J] Shaanxi Normal University, 2002 (3). 